\title{
"Estudos para uma bailadora andaluza" e os elementos do flamenco
}

\author{
Isadora Eckardt da Silva*
}

\begin{abstract}
Resumo: No presente trabalho, pretende-se analisar o poema "Estudos para uma Bailadora Andaluza", escrito por João Cabral de Melo Neto. E, partindo de elementos da dança flamenca, mostrar como tais elementos aparecem ao longo do texto. Este se divide em seis partes, referindo-se cada uma delas a um ou mais elementos específicos do flamenco. A primeira parte se refere a um dos palos flamencos, a siguiriya, e a el doende, um elemento do folclore desta dança. A segunda trata de quem conduz o ritmo da dança, se é a bailarina ou o músico. A terceira faz referência ao caráter percussivo do flamenco, com sua contagem de tempos e compassos. A quarta é sobre o estilo do sapateado nesta dança. A quinta se refere às paradas que a dançarina realiza ao longo da coreografia, chamadas "cortes". E, finalmente, a sexta parte do poema trata das roupas usadas pelas bailarinas de flamenco.
\end{abstract}

\begin{abstract}
The objective of this text is to analyze the poem "Estudos para uma Bailadora Andaluza", written by João Cabral de Melo Neto. Considering the elements that come from Spanish dance (Flamenco), the aim is to show how these elements appear throughout the text. This poem is divided in six parts, each one of them referring to one or more specific elements from Flamenco. The first part refers to the siguiriya, one of the rhythms of Flamenco, and it also refers to el doende, one element of the folklore of this type of dance. The second part is about who conducts the rhythm, if it is the dancer or the musician. The third one is about the way rhythm is measured in Flamenco. The fourth one is about the style of stepping used in this dance. The fifth part tells of the ways the dancers pause dancing, whenever they have to. Finally, the last part is about the clothing used in Flamenco.
\end{abstract}

A arte Flamenca, tal qual a conhecemos nos nossos dias, é resultante do processo evolutivo de uma manifestação sócio-cultural que se inicia na região de Andaluzia, sul da Espanha, no final do século XVIII. Suas bases musicais, rítmicas e poéticas assentam-se na riqueza do folclore andaluz, resultado da mescla de povos e culturas que povoaram essa região ao longo da história, tais como: ciganos, árabes e judeus.

A origem dos diferentes estilos (chamados Palos) do Flamenco situa-se, principalmente, na região composta pelas cidades de Sevilha, Cádiz e Granada. Outras províncias de Andaluzia, bem como outras regiões da Espanha, como Extremadura e Múrcia, também contribuíram com diferentes estilos e com suas ramificações.

\footnotetext{
* Isadora Eckardt da Silva é graduada em Letras pela UFRGS e mestranda em Teoria e História Literária pela UNICAMP.
} 
Os Palos fundamentais do Flamenco são as Soleares, as Siguiriyas, os Tangos e os Fandangos, dos quais derivam os demais ritmos.

Os primeiros relatos de manifestações de uma dança ancestral à Flamenca foram feitos por intelectuais estrangeiros, que visitavam a Espanha e que, nos bairros periféricos, não freqüentados pelos espanhóis abastados, descobriram as primeiras tabernas onde esses artistas primitivos se apresentavam. Nessa época, final do século XVIII, era feita uma mistura de bailes populares, flamencos e escola bolera (bailes com castanholas). Pouco a pouco o estilo flamenco foi se impondo e incorporando elementos de outras danças, até formar suas próprias características.

Profissionalmente, a Dança Flamenca se consolidou nas festas organizadas pelas "Academias de Baile de Sevillanas" e em alguns locais típicos como as "Cuevas del Sacromonte", em Granada (bairro habitado principalmente por ciganos). Mas é nos Cafés Cantantes, surgidos no final do século XIX, que a dança Flamenca, bem como a forma de cantar e tocar Flamenco, adquire sua personalidade definitiva.

A partir de então, a Dança Flamenca evolui técnica e cenicamente, atingindo "status" de escola de dança, hoje apreciada e praticada nos mais diferentes países, tais como: Japão, Inglaterra, Bélgica, França, Estados Unidos, Alemanha e praticamente toda a América Latina.

O poeta pernambucano João Cabral de Melo Neto trabalhou na embaixada do Brasil na Espanha, tendo assim desenvolvido uma grande paixão pelo Flamenco e suas bailarinas. Devido a essa paixão, João Cabral escreveu um poema dividido em seis partes sobre estas bailarinas, o qual tratarei no presente trabalho: Estudos para uma Bailadora Andanluza.

O poeta faz claras referências a elementos do Flamenco ao longo do poema, denotando que não era um mero admirador desta dança, ao contrário, ele entendia de fato como ela funcionava e quais elementos a compunham.

Na primeira parte do poema, João Cabral começa fazendo referência a um dos palos flamencos, a siguiriya. Este palo é sempre usado em músicas tristes, com letras chorosas e melancólicas. A origem destes palos tristes está no fato de que os ciganos sempre foram um povo que sofreu muitas perseguições e era sempre excluído da sociedade, portanto, eles cantavam e dançavam tais músicas tristes para expressar a sua dor perante à vida. Assim, esses ritmos tristes, quando dançados, exigem que a bailarina se mantenha sempre séria, pois não comportaria com esta dança uma expressão sorridente.

Nos versos em que fala "carne em agonia", "só nervos" e "carne toda em carne viva", o poeta está se referindo a el duende. De acordo com o folclore da dança Flamenca, el duende é uma espécie de entidade, de espírito, que toma conta da bailarina na hora de dançar. É como 
se a bailarina incorporasse este espírito, pois o Flamenco não é dançado com frieza, é preciso haver sentimento, é quase como se fosse algo teatral. Portanto, os versos fazem referência a esse transe no qual a bailarina entra na hora de dançar.

Nos versos que dizem que a bailarina é capaz de "acender-se estando fria" e "incendiar-se com nada", o poeta menciona sentimentos trazidos por el duende, pois se o Flamenco não pode ser dançado friamente, o oposto disso é o calor, o fogo que uma bailarina deve trazer consigo.

Na segunda parte do poema, João Cabral fala na "parte que domina" e na "parte que se rebela", ou seja, que nesta dança há alguém que manda e alguém que obedece. Aqui ele faz referência ao fato de que, no Flamenco, dependendo da ocasião, a bailarina segue a música, ou a música segue a bailarina.

Quando mais de uma bailarina está dançando, todas devem seguir o mesmo ritmo para não haver disparidade na coreografia. Neste caso, então, quem dita o ritmo é o guitarrista, que deve ser seguido pelas bailarinas. Daí o poeta comparar a bailarina com uma cavaleira, pois ela é levada pela música assim como a cavaleira é levada pela égua.

No entanto, quando uma bailarina está dançando sozinha, ela poderá dançar no ritmo que desejar, precisando o guitarrista segui-la com sua guitarra. Neste caso então, quem dita o ritmo da música é a bailarina. Daí o poeta compará-la a uma égua, pois aqui é ela que conduz a música e a dança, assim como é a égua que leva a cavaleira.

Na terceira parte do poema, João Cabral faz referência ao caráter percussivo da dança flamenca. Afinal, esta baseia todas as suas coreografias nos ritmos dos diferentes palos, cada um com sua própria contagem de tempos e compassos.

Quando o poeta diz que a bailarina "a cabeça, atenta, inclina,/como se buscasse ouvir/alguma voz indistinta”, está fazendo alusão ao fato de que a bailarina precisa primeiro ouvir um ou dois compassos da música para captar a velocidade e a contagem de seu ritmo, para só depois começar a dançar, pois o compasso da bailarina e o dos músicos devem estar sempre em sintonia. O poeta compara esta percussão e esta sintonia com a telegrafia e com o código morse.

Por ser a telegrafia uma espécie de comunicação, o poeta faz alusão a um diálogo no qual a bailarina participa quando menciona "a mensagem transmitida", "aquelas respostas/que suas pernas pronunciam" e "do outro lado da linha", só para citar alguns exemplos. E de fato, há um diálogo no Flamenco entre a bailarina e o músico que se compõe de alguns tipos de mensagens, tais como: a chamada, a marcação da letra e os jaleos. 
A 'chamada' é um sapateado que a bailarina faz, normalmente mais ruidoso, para avisar o guitarrista de alguma coisa. Ela pode tanto querer avisar que vai começar a dançar, como que vai parar de fazê-lo, ou ainda que fará apenas uma pausa. Na hora em que estas chamadas são realizadas, pode haver música, mas nunca há canto, para que este não 'faça barulho' atrapalhe o sapateado.

A 'marcação de letra' é justamente o oposto da chamada, ou seja, a bailarina apenas marca a música, mas não sapateia porque há canto. A bailarina pára o sapateado para avisar aos músicos que, neste momento, eles podem cantar, e ela fará silêncio.

Os jaleos são estímulos gritados para animar a dança. Eles podem tanto ser da parte da bailarina, como da parte dos músicos ou das pessoas da platéia. É a estas "conversas" que o poeta faz referência nesta parte do poema.

Na quarta parte do poema, João Cabral compara o jeito que um camponês trata a terra com o jeito que a bailarina trata o tablado, dizendo que ambos tencionam amaciar o solo. Aqui o poeta está fazendo referência ao estilo do sapateado na dança flamenca. No sapateado americano, os bailarinos apenas tocam de leve o tablado, fazendo um som mais agudo e baixo. Já no Flamenco, a bailarina precisa bater o pé com força no tablado, produzindo assim um som grave e na maioria das vezes alto. Há clara referência à força e à energia deste sapateado nos seguintes versos: "Ela não pisa na terra/como quem a propicia/para que lhe seja leve", "Ela a trata com a dura/e muscular energia".

Nesta parte do poema, fala-se que as bailarinas normalmente possuem pernas muito fortes, dada a força empregada no seu sapateado. João Cabral descreve essas pernas como "pelos troncos dessas pernas/fortes, terrenas, maciças".

Na quinta parte do poema, João Cabral diz que, em alguns momentos, a bailarina pode ser comparada a uma estátua, o que pode ser notado nos seguintes versos: "com a mesma posição/como que talhada em pedra:/um momento está estátua”.

O poeta alude aos 'cortes', que tanto podem estar no meio da coreografia, como podem ser o movimento derradeiro, aquele que encerra a coreografia. O corte na música normalmente se trata de uma pausa, e a bailarina segue essa pausa sonora com uma parada em seus movimentos. A pausa da bailarina pode ser feita com diversos 'movimentos de corte', como uma virada de cabeça, um movimento de braços ou um golpe de sapateado. E durante estas pausas, a bailarina fica como uma estátua, não mexe nem os olhos, respira de leve, tudo para não se mexer mesmo. Nestes momentos, a bailarina se parece com uma estátua, imóvel e impassível, exatamente como nos versos. O contrário dos movimentos cortados, então, são os movimentos contínuos. 
Na última parte do poema, João Cabral faz referência às roupas usadas pelas bailarinas na dança flamenca, como diz no seguinte verso: "saias folhudas e crespas". Tradicionalmente, o Flamenco é dançado com vestidos ou saias com muito pano. Isto significa saias muito rodadas e com muitos babados que também são usados na dança para "dançarem junto com a bailarina", ao girarem junto com ela em seus corrupios. A bailarina também pega em sua saia para balançá-la e fazê-la dançar com ela.

O poeta também destaca os movimentos de braços e mãos feitos pela bailarina nos seguintes versos: "mas também dessa outra flora/a que seus braços dão vida". Ao comparar os braços com a flora, ele está fazendo uma alusão aos braços da bailarina que podem ficar compridos como galhos longos, ou curvados como galhos torcidos, dependendo da coreografia e do estilo da bailarina. O braço esticado é inspirado na postura do balé clássico, enquanto o braço curvado tem sempre sua curva feita no cotovelo e foi herdado das danças mais tristes dos ciganos, pois a bailarina fica mais 'fechada' com esta postura.

Já os movimentos das mãos se parecem com flores, tanto é que se diz que as mãos de uma bailarina de Flamenco devem ter "floreios". Uma mão com floreios quer dizer que a bailarina quebra bastante o pulso para girar a mão e separa bem os dedos ao fazer estes giros, fazendo assim as mãos se parecerem com flores que desabrocham. Daí o poeta fazer menção à flora.

\section{Referências}

ARREBOLA, Alfredo. La Espiritualidad en el Cante Flamenco. Cadiz: Universidad de Cadiz, 1988.

GULARTE, Washington. Brasil Bajo el Embrujo Flamenco. Porto Alegre: Orvalho Andaluz, 1995. 